\title{
The impact of epidemic infectious diseases on the wellbeing of migrant workers: A systematic review
}

\author{
Fei Wang · Chao Tian · Weidi Qin
}

\begin{abstract}
Background: The COVID-19 outbreak poses challenges to people across the world and puts marginalized populations in an even more precarious position. Migrant workers, with their marginal socio-legal status in host countries, are especially vulnerable during the pandemic. The wellbeing of migrant workers, specifically low-wage laborers, is greatly compromised. Objectives: This study aims to systematically review the existing literature on how epidemic infectious diseases affect the wellbeing of migrant workers and what are the interventions to improve their wellbeing. Method: Following the PRISMA guideline, studies on migrant workers' wellbeing or interventions to improve wellbeing during five major epidemic infectious diseases (i.e., COVID19, SARS, Ebola, H1N1, MERS) were searched. Eleven electronic databases were used: Cochrane Library, WHO Global Research COVID-19 database, APA PsycInfo, CINAHL Plus, ERIC, MEDLINE, Social Index, PubMed, ProQuest, Social Care Online and EPPI-Mapper. In total, 17 articles that met the criteria were included. An assessment guide was developed to examine the quality of the studies. Results: Overall, the studies consistently show that major epidemic outbreaks negatively affect the physical, financial, psychological and social wellbeing of migrant workers. Migrant workers face a wide range of challenges such as risks of contagion, job insecurity, psychological distress, and discrimination. Factors associated with migrant workers' marginal socio-economic status were attributed to these challenges. Several interventions were discussed including increased access to vaccinations, health screening at the border, promotion of hygiene strategies, and financial assistance in medical fees. Discussion: The findings highlight the need for a greater public awareness and stronger response to migrant workers' wellbeing during an epidemic outbreak. Implications to practice and research were discussed. This review calls for more open-access data to advance research on migrant workers, and evidence-based interventions with a long-term effect.
\end{abstract}

Keywords: Migrant worker, wellbeing, intervention, epidemic infectious disease 


\section{Practice implications}

Based on the findings and gaps in the existing studies, the present review provides important implications for practice with and research on migrant workers during epidemic outbreaks.

- Given that limited interventions regarding psychological wellbeing were identified in the studies, practitioners should focus their efforts in developing and tailoring interventions that can improve the psychological wellbeing of migrant workers during epidemic outbreaks. In view of the difficulty in providing in-person support due to social distancing, new interventions that involve technology should be considered, such as online counseling or online support groups.

- Practitioners can disseminate evidence-based information on the cause and transmission of the disease using social media, combating rumors and misinformation that could lead to xenophobia against migrant workers. Furthermore, through sharing migrant workers' stories and voices, practitioners can raise the public awareness to migrant workers' challenges and advocate for migrant-inclusive response measures.

- Interventions that address the long-term impact of epidemics on migrant workers should be developed. Migrant workers face the risks of unemployment and deportation due to economic downturn post-outbreak. Governments should register migrant workers to the official unemployment record, conduct a demand and supply analysis in different industries, and relocate migrant workers to the industries where there is a labor shortage.

- More evidence-based research is needed to examine the effectiveness of interventions for migrant workers during epidemics. This could be supported by increasing data accessibility. Specifically, the International Organization for Migration can collaborate with research institutes and NGOs to develop a migrant worker data sharing platform. The data will not only boost migrant worker research, but also provide evidence for service delivery and policy development in preparation for future epidemics.

\section{Introduction}

The outbreak of a new coronavirus (COVID-19) has spread internationally since the initial report of cases by the Wuhan Municipal Health Commission, China on 31 December 2019 (WHO, 2020). It was declared a pandemic by the World Health Organization on March 11th 2020 and has - as of June 2020 - seen over 5 million confirmed cases and over 356,000 related deaths worldwide (John Hopkins University \& Medicine, 2020). It has become evident that the pandemic will have a long-lasting and substantial influence on people's wellbeing, far beyond physical health.

Although there is an increasing body of research on the wellbeing of vulnerable populations in the COVID-19 pandemic such as healthcare workers and older adults, little attention has been paid to migrant workers. Migrant workers (used interchangeably with "migrants"), are defined as "Foreigners admitted by the receiving State for the specific purpose of exercising an economic activity remunerated from within the receiving country" (United Nation Statistical Division, 1998, p.14). The life of migrant workers often consists of multiple layers of precarity as a result of their marginal socio-legal status and labor market position, and limited rights in the host country (Baey \& Yeoh, 2018).

During the COVID-19 pandemic, this precarity has risen to an unprecedented level. Of the 164 million international migrant workers worldwide, 95\% reside in the five WHO regions in which COVID-19 cases have been confirmed (Liem, Wang, Wariyanti, Latkin, \& Hall, 2020). Some countries (e.g., Singapore, India) have seen a surge in COVID-19 cases among migrant workers. The wellbeing of migrant workers, specifically unskilled laborers, is greatly 
compromised. With the effect of travel bans, many are not able to travel home. They have been stranded at public transit and risk being exposed to the virus (Erizanu, 2020). Migrant workers who work in essential critical infrastructure (e.g., healthcare, deliveries, and agriculture) continue working through the pandemic, which increases their risk of being infected. In addition, migrant workers in the hardest-hit industries (e.g., tourism, construction, and accommodation and food services) experience financial strain due to possible loss of employment following the pandemic, more so than native-born workers (World Bank, 2020). These crises are exacerbated by a series of social factors such as language barriers, limited social contacts, and being unjustly discriminated against for spreading the COVID-19 virus (Guadagno, 2020), which could trigger negative emotions and ultimately affect mental health.

In the wellbeing literature, although there is no consensus around a single definition of wellbeing, a general agreement is that at minimum, wellbeing includes a positive judgment of one's life, the presence of positive emotions, and the absence of negative emotions (the U.S. Centers for Disease Control and Prevention, 2018). In addition, scholars generally acknowledge that wellbeing is a multi-faceted concept, with several important aspects identified across disciplines such as physical, financial, psychological, and social (Diener \& Biswas-Diener, 2008; Kobau et al., 2013; Andrews \& Withey, 1976; Frey \& Stutzer, 2002). Several theories highlight the interrelationships between socioeconomic status, resources, and wellbeing, all of which help explain why migrant workers are particularly vulnerable during the pandemic. Hobfoll's Conservative of Resource Theory (1989) suggests that people strive to retain, protect and build resources in order to maintain their wellbeing. However, because resources are not distributed equally across different socioeconomic statuses, those with a low socioeconomic status are most vulnerable to a depletion of resources (Hobfoll, 1989). Furthermore, they are more likely to be caught in loss spirals because they lack resources to prevent the further loss of other resources (Menaghan, 1983). Fisher (2019) expanded on Hobfoll's idea and developed the public wellbeing theory. He suggests that well-being is largely dependent on the objective nature of the situation as well as people's subjective evaluation. Therefore, the inequalities in well-being are both shaped by the social conditions people are exposed to, specifically by differences in socioeconomic status, and negative evaluations people receive from the society (Fisher, 2019). For migrant workers, their vulnerability lies in low socio-economic status and disproportionate exposure to social discrimination. During this pandemic, the existing social inequities have been exacerbated, leaving them with limited resources or no resources to meet the challenges and maintain their well-being.

\section{Study Objectives}

Despite seemingly apparent anecdotal evidence as to the negative impact on migrant workers' well-being, few studies, if any, have examined this impact. This study aims to fill the research gap by addressing the following questions:

1. What are the impacts of major epidemic infectious diseases on migrant workers' wellbeing?

2. What community and population-level interventions have been taken to improve the well-being of migrant workers following an epidemic outbreak?

\section{Methods}

A systematic review was conducted to address the research questions above. To the best of our knowledge, there are no prior systematic reviews specifically focus on migrant workers during the COVID-19 pandemic. Reviews that included the previous epidemic outbreaks are 
minimal (Wilson et al., 2018). The sweeping impact of COVID-19 calls for an urgent response. A systematic review is an efficient approach to synthesize available research evidence and deliver it to healthcare providers, researchers, policymakers, and the general public. Furthermore, by critically examining existing interventions, this review will help inform new interventions to meet the challenges posed by the current pandemic as well as epidemics in the future.

\section{Type of Study}

The inclusion criteria for study types were intervention study, observational studies using cross-sectional or longitudinal designs, mixed-methods studies, qualitative studies, descriptive, correlational studies or case studies, theoretical or position paper, editorial, commentary, systematic reviews, and practice guideline. Anecdotal accounts and news articles were excluded.

\section{Study Subjects}

The subjects for the review were unskilled migrant workers - a group which is especially vulnerable during epidemics due to low socioeconomic status and limited resources. We adopted the UN definition of migrant workers (see Introduction; United Nation Statistical Division, 1998). We also included internal migrant workers - people who move within their own country of residence for the purpose of employment (International Organization for Migration, 2005). This inclusion is justified by the significant number of internal migrant workers across the world (International Organization for Migration, 2020). Like international migrant workers, internal migrant workers also experience the challenges such as discrimination and difficulties in integration (Jane, 2016; Qiu, 2011).

\section{Search Strategy}

The following 11 electronic databases were used to search literature: Cochrane Library, WHO Global Research COVID19 database, APA PsycInfo, CINAHL Plus, ERIC, MEDLINE, Social Index, PubMed, ProQuest, Social Care Online and EPPI-Mapper. Articles were searched from 2000 to 2020. The rationale for the time range is that it includes the major epidemic infectious diseases in the 21st century. These diseases are Middle East Respiratory Syndrome (MERS), influenza A virus subtype H1N1 (H1N1), Severe Acute Respiratory Syndrome (SARS), Ebola Virus Disease, and Coronavirus Disease 2019 (COVID-19). Because the review focuses on emerging infectious diseases, that is, one that appears for the first time in a population or rapidly increases in incidence or geographic range (World Health Organization, 2014), studies looking at seasonal influenza were excluded.

The search string used for the database was:

(migrant workers OR foreign workers OR internal migrant workers OR domestic helpers)

\section{AND/OR (interventions)}

AND (psychological OR physical OR economic OR social)

AND (COVID-19 or SARS or Ebola or H1N1 or MERS)

The search string was conducted in the field of title and abstract and was consistent across the databases. Anecdotal accounts or news articles resulting from the searches were filtered out in the databases.

\section{Data Management}

All identified citations were imported to Mendeley, a bibliographic reference management tool, and de-duplicated. A table was created as a data extraction form to record 4 parts: study 
information, initial screening, eligibility decisions and quality assessment (see Appendix I). The de-duplicated citations in Mendeley were imported to the data extraction form for coding.

\section{Selection of Studies}

Two coders screened the titles and abstracts of articles for initial screening and completed the data extraction form independently. Articles about unskilled migrant workers and major epidemic infectious diseases were included for the full-text review. A study was also included for full-text review if its title and abstract were insufficient to determine its inclusion. Disagreements on initial screening were resolved by a third coder.

After initial screening, two coders reviewed the full-text of the articles independently to determine their eligibility. An article is considered eligible if it is about (1) the wellbeing of migrant workers or (2) the interventions to improve the wellbeing of migrant workers. Disagreements on eligibility decisions were resolved by a third coder. Final decision on eligibility and reasons for exclusion of studies were documented on the data extraction form.

\section{Assessment of Quality}

After identifying the eligible studies, the coders further assessed the quality of these studies using a checklist (see Appendix II) adapted from Joanna Briggs Institute Checklist for Prevalence Studies and Qualitative Studies (Joanna Briggs Institute, 2017). The checklist comprised 9 items such as use of clearly defined participants, scientifically valid sampling technique, and the scope of wellbeing and interventions discussed. Two coders independently rated the items in the checklist, and marked as Yes (1), No (0), or "Uncertain" on the assessment form. Any items marked as "Uncertain" were rated by the third coder. Studies scoring 1-3 were defined as low quality, 4-6 as medium quality, and 7-9 as high quality. Studies were not excluded on the basis of their quality score to increase transparency and to ensure all available evidence in this area was reported.

\section{Results}

The study selection process and reasons for exclusion followed the Preferred Reporting Items for Systematic Reviews and Meta-Analysis (PRISMA), as illustrated in Figure 1. 


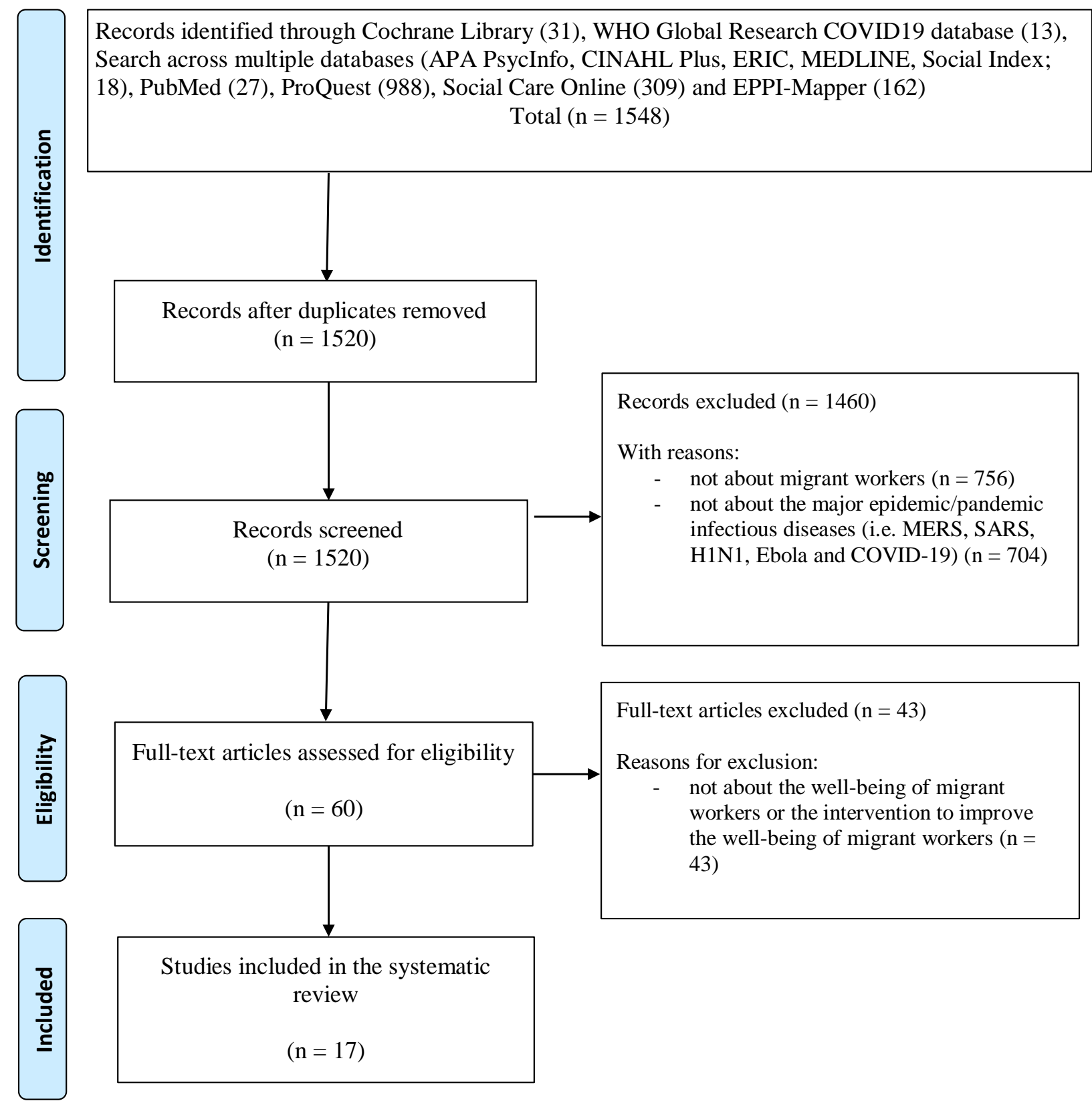

Figure 1. Preferred reporting items for systematic reviews and meta-analysis (PRISMA) flow diagram. 
In total, 1548 studies were identified through database searching; 17 studies met the inclusion criteria and were further analyzed for the present review. The characteristics and main findings of these studies are presented in Table 1.

Table 1. Study characteristics and main findings

\begin{tabular}{|c|c|c|c|c|c|c|}
\hline $\begin{array}{l}\text { Author } \\
\text { (year) } \\
\text { \& Study } \\
\text { type }\end{array}$ & $\begin{array}{c}\text { Target } \\
\text { populati } \\
\text { on } \\
\& \\
\text { Country }\end{array}$ & $\begin{array}{l}\text { Epidemic } \\
\text { types }\end{array}$ & $\begin{array}{l}\text { Type of } \\
\text { Wellbeing } \\
\text { Discussed }\end{array}$ & Interventions & Summary of findings & $\begin{array}{l}\text { Quality } \\
\text { of } \\
\text { Study }^{1}\end{array}$ \\
\hline $\begin{array}{l}\text { The Lancet } \\
(2020) \\
\text { Commentary }\end{array}$ & $\begin{array}{l}\text { Migrants } \\
\& \\
\text { Refugees } \\
\text { Global }\end{array}$ & COVID-19 & Physical & - & $\begin{array}{l}\text { Physical } \\
\text { - Challenges in accessing essential supplies } \\
\text { and medical care due to migratory status }\end{array}$ & 2 \\
\hline $\begin{array}{l}\text { Bhopal } \\
(2020) \\
\text { Commentary }\end{array}$ & $\begin{array}{l}\text { Migrants } \\
\text { U.K. }\end{array}$ & COVID-19 & $\begin{array}{l}\text { Physical } \\
\text { Social }\end{array}$ & - & $\begin{array}{l}\text { Physical } \\
\text { - Difficulty applying precautions due to } \\
\text { poor living environment } \\
\text { - Limited access to healthcare services due } \\
\text { to migratory status } \\
\text { Social } \\
\text { - Lack of trust in the government and } \\
\text { employer } \\
\text { - Lack of legal rights } \\
\text { - } \text { Cultural and language barriers in } \\
\text { High risk of becoming victims of social } \\
\text { discrimination }\end{array}$ & 2 \\
\hline $\begin{array}{l}\text { Lin et al. } \\
\text { (2015) } \\
\text { Commentary }\end{array}$ & $\begin{array}{l}\text { Migrant } \\
\text { workers } \\
\text { China }\end{array}$ & Ebola & Social & Yes & $\begin{array}{l}\text { Social } \\
\text { - } \quad \text { Racial discrimination and stigma against } \\
\text { African migrant workers who lived in } \\
\text { China during the Ebola outbreak } \\
\text { Interventions } \\
\text { - Temperature monitoring } \\
\text { - Immigration border health screening } \\
\text { - } \quad \text { Location tracing }\end{array}$ & 3 \\
\hline
\end{tabular}

1 The quality of the studies is measured using an 9-item checklist adapted from Joanna Briggs Institute Checklist for Prevalence Studies and Qualitative Studies (Joanna Briggs Institute, 2017). Studies scoring 1-3 are defined as low quality, 4-6 as medium quality, and 7-9 as high quality. 


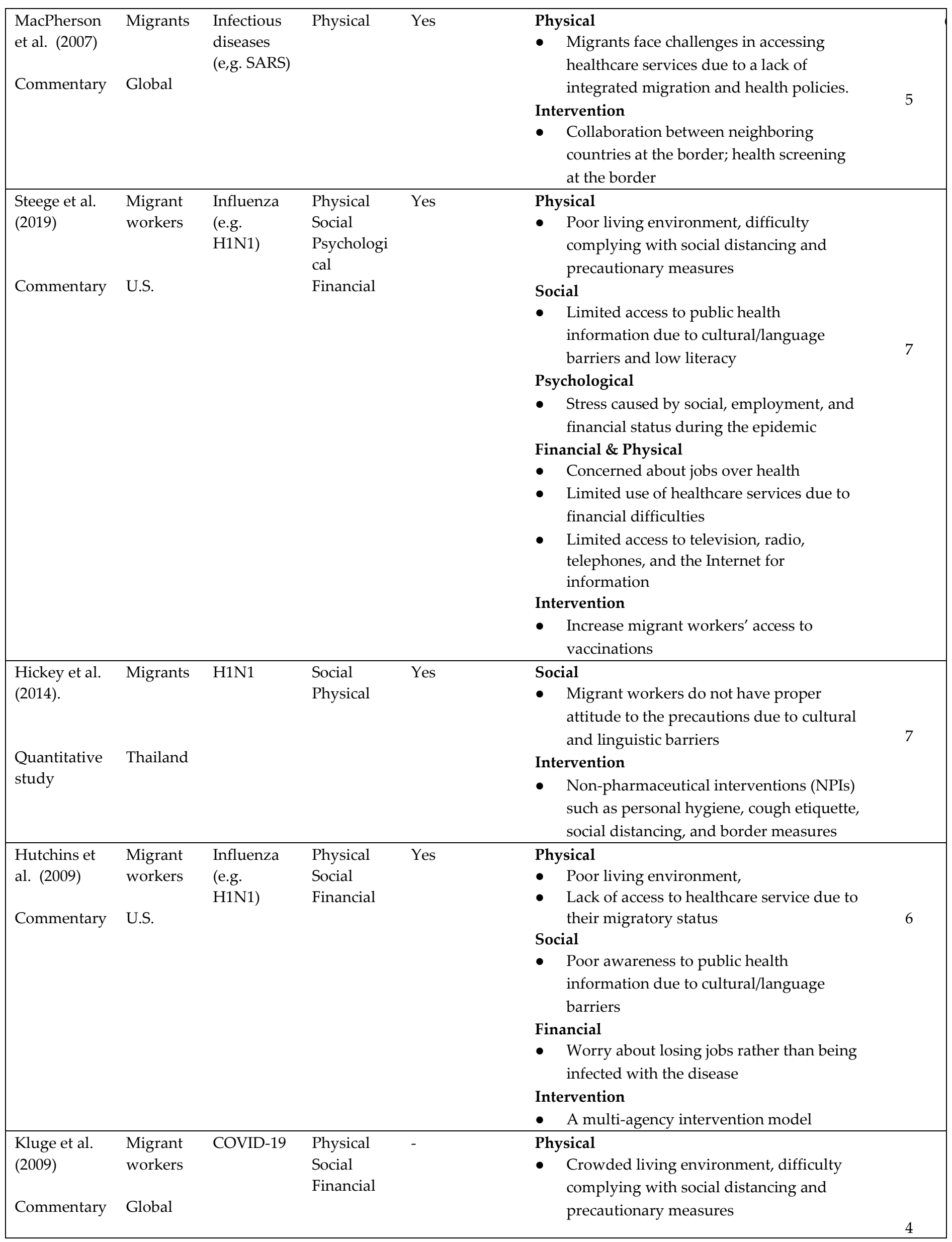




\begin{tabular}{|c|c|c|c|c|c|c|}
\hline & & & & & $\begin{array}{l}\text { Social } \\
\text { - Limited awareness to public health } \\
\text { information in the host country due to } \\
\text { cultural/language barriers } \\
\text { Financial \& Physical } \\
\text { - Worry about being unemployed and } \\
\text { losing income } \\
\text { Limited use of healthcare services due to } \\
\text { financial difficulties }\end{array}$ & \\
\hline $\begin{array}{l}\text { Biao (2003) } \\
\text { Qualitative } \\
\text { study }\end{array}$ & $\begin{array}{l}\text { Migrant } \\
\text { workers } \\
\text { China }\end{array}$ & SARS & $\begin{array}{l}\text { Social } \\
\text { Financial } \\
\text { Physical }\end{array}$ & Yes & $\begin{array}{l}\text { Social } \\
\text { - Lack of trust in the government and } \\
\text { employer } \\
\text { - Virus outbreak led to mass mobilization } \\
\text { of migrant workers, which increased the } \\
\text { spread of the virus } \\
\text { Financial \& Physical } \\
\text { - Migrant workers were less concerned } \\
\text { about their health, more concerned about } \\
\text { their job due to their unstable } \\
\text { employment status } \\
\text { - Continue working during the outbreak in } \\
\text { order to support the family and pay off } \\
\text { collateral loan } \\
\text { Intervention } \\
\text { - A multi-agency intervention model }\end{array}$ & 9 \\
\hline $\begin{array}{l}\text { Schoch- } \\
\text { Spana et al. } \\
(2010) \\
\text { Qualitative } \\
\text { study }\end{array}$ & $\begin{array}{l}\text { Migrant } \\
\text { workers } \\
\text { Mexico }\end{array}$ & H1N1 & $\begin{array}{l}\text { Physical } \\
\text { Social } \\
\text { Financial }\end{array}$ & - & $\begin{array}{l}\text { Physical } \\
\text { - High rates of pre-existing medical } \\
\text { conditions } \\
\text { - } \quad \text { Poor living conditions lead to difficulty } \\
\text { taking precautions } \\
\text { Social } \\
\text { - Limited access to public health } \\
\text { information due to cultural/language } \\
\text { barriers and low literacy } \\
\text { - } \quad \text { Fack of social support } \\
\text { - } \quad \text { Social discrimination and stigmatization } \\
\text { Financial \& Physical } \\
\text { - } \quad \text { Worry about being unemployed } \\
\text { - } \quad \text { Limited use of healthcare services due to } \\
\text { financial difficulties }\end{array}$ & 7 \\
\hline $\begin{array}{l}\text { Onoma } \\
(2017) \\
\text { Commentary }\end{array}$ & $\begin{array}{l}\text { Migrants } \\
\text { Senegal }\end{array}$ & Ebola & Social & - & $\begin{array}{l}\text { Social } \\
\text { - Racial discrimination and stigmatization }\end{array}$ & 3 \\
\hline $\begin{array}{l}\text { Liem et al. } \\
(2020)\end{array}$ & $\begin{array}{l}\text { Migrant } \\
\text { workers }\end{array}$ & COVID-19 & $\begin{array}{l}\text { Psychologi } \\
\text { cal } \\
\text { Social }\end{array}$ & - & $\begin{array}{l}\text { Psychological } \\
\text { - Migrant workers suffer from mental } \\
\text { health issues (e.g., depression) due to their } \\
\text { limited social resources } \\
\text { Social } \\
\text { - } \quad \text { Stigmatization } \\
\text { - } \quad \text { Limited access to public health } \\
\text { information and are easily affected by } \\
\text { misinformation due to cultural/language } \\
\text { barriers and low literacy }\end{array}$ & 4 \\
\hline
\end{tabular}




\begin{tabular}{|c|c|c|c|c|c|c|}
\hline $\begin{array}{l}\text { Ding (2014) } \\
\text { Theoretical } \\
\text { paper }\end{array}$ & $\begin{array}{l}\text { Migrant } \\
\text { Workers } \\
\text { China \& } \\
\text { North } \\
\text { America }\end{array}$ & $\begin{array}{l}\text { SARS \& } \\
\text { H1N1 }\end{array}$ & $\begin{array}{l}\text { Physical } \\
\text { Financial } \\
\text { Psychologi } \\
\text { cal }\end{array}$ & Yes & $\begin{array}{l}\text { Physical } \\
\text { - Poor living conditions result in difficulty } \\
\text { in practicing precautions } \\
\text { Financial \& Physical } \\
\text { - Worry about being losing jobs } \\
\text { - Limited use of healthcare services due to } \\
\text { financial difficulties } \\
\text { Psychological } \\
\text { - Stress and anxiety during the epidemic } \\
\text { outbreaks due to uncertainty about the } \\
\text { future } \\
\text { Interventions } \\
\text { - } \quad \text { Quarantine } \\
\text { A multi-agency intervention model } \\
\text { - Special government fund for migrant } \\
\text { workers with SARS } \\
\text { Employers were required to continue } \\
\text { paying wages to workers even though } \\
\text { their work was suspended during the } \\
\text { outbreak }\end{array}$ & 7 \\
\hline $\begin{array}{l}\text { Daniels } \\
(2020) \\
\text { Commentary }\end{array}$ & $\begin{array}{l}\text { Migrants } \\
\text { Venezuel } \\
\text { a }\end{array}$ & COVID-19 & $\begin{array}{l}\text { Physical } \\
\text { Social }\end{array}$ & Yes & $\begin{array}{l}\text { Physical } \\
\text { - Lack of food and medical supplies } \\
\text { - } \quad \text { Limited access to healthcare services due } \\
\text { to migratory status } \\
\text { Social } \\
\text { - Social discrimination and stigmatization } \\
\text { Interventions } \\
\text { - Quarantine } \\
\text { - } \quad \text { Border control } \\
\text { - Cross border permission for migrant } \\
\quad \text { workers who need ongoing treatment in } \\
\quad \text { the host country }\end{array}$ & 4 \\
\hline
\end{tabular}

Overall, a majority of the studies adopted a global perspective $(\mathrm{N}=4)$ whereas others were conducted across a wide range of countries and regions, including the U.S. $(\mathrm{N}=3)$, China $(\mathrm{N}=$ 3), Europe $(\mathrm{N}=2)$, the U.K. $(\mathrm{N}=1)$, Mexico $(\mathrm{N}=1)$, Senegal $(\mathrm{N}=1)$, Venezuela $(\mathrm{N}=1)$ and Thailand $(\mathrm{N}=1)$. The studies are mostly commentaries while only a few are empirical studies ( $\mathrm{N}$ =4). With regards to the disease type, the majority of the studies focused on COVID-19 $(\mathrm{N}=7)$, followed by SARS $(\mathrm{N}=4)$ and H1N1 $(\mathrm{N}=4)$, and Ebola $(\mathrm{N}=2)$. The overall quality of the studies is medium, with an average score of 5.06. Compared to studies on other epidemics, COVID-19 related articles are of lower quality (COVID-19 $=3.71$; other epidemics $=6$ ).

\section{Wellbeing}

Overall, all 17 studies discussed the negative impact of epidemic infectious diseases on the wellbeing of migrant workers. While the majority of the studies focus on physical, social and financial wellbeing, only a few studies have examined psychological wellbeing. Nonetheless, the 
negative impact of epidemics is consistently described across studies focusing on different aspects of wellbeing.

\section{Physical wellbeing}

Twelve studies focused on migrant workers' physical wellbeing. Manual laborers who live in crowded environments are most vulnerable to diseases due to difficulty complying with social distancing and precautionary measures (Ding, 2014; Steege, Baron, Davis, Torres-Kilgore, \& Sweeney, 2019; Bhopal, 2020; Hutchins, Truman, Merlin, \& Redd, 2009; Kluge, Jakab, Bartovic, Danna, \& Severoni, 2009; Schoch-Spana, Bouri, Rambhia, \& Norwood, 2010; EUPHA, 2020). In addition, studies show that migrant workers do not have full-access to healthcare services due to their migratory status (Daniels, 2020; Bhopal, 2020; Rothstein \& Coughlin, 2019; PICUM, 2020; Hutchins et al., 2009; The Lancet, 2020; MacPherson, Gushulak, \& Macdonald, 2007).

Social wellbeing

Fourteen articles focused on social wellbeing. Migrant workers received limited social support during epidemics (PICUM, 2020; Schoch-Spana et al., 2010). Also, migrant workers' lack of trust in their employers and the government could hinder them from seeking help from either party (Bhopal, 2020; Rothstein \& Coughlin, 2019; Biao, 2003; EUPHA, 2020). Furthermore, social discrimination and cultural stigma targeting migrant workers could create barriers for them to access resources during epidemic outbreaks (Lin, Hall, Khoe, \& Bodomo, 2015; Liem et al., 2020; Daniels, 2020; Bhopal, 2020; Schoch-Spana et al., 2010; Onoma, 2017). In addition, migrant workers may be easily affected by misinformation about diseases due to language and cultural barriers in the host country (Liem et al., 2020). Furthermore, linguistic barriers in understanding public health information could result in poor awareness to disease control regulations (Steege et al., 2019; Kluge et al., 2020; Hickey, Gagnon, \& Jitthai, 2014; Bhopal, 2020; Hutchins et al., 2009; EUPHA, 2020).

\section{Financial wellbeing}

Seven studies found that epidemic outbreaks cause economic disruptions, creating a financial burden on migrant workers. Migrant workers often limit their use of healthcare services when they are sick due to financial difficulties (Ding, 2014; Steege et al., 2019; Kluge et al., 2020; SchochSpana et al; 2010). During an outbreak, migrant workers were concerned about their jobs over health (Biao, 2003; Steege et al., 2019; Hutchins et al., 2019; Kluge et al., 2020; Schoch-Spana et al; 2010; Ding, 2014; PICUM, 2020). Many chose to continue working in order to support their families or pay off collateral loans (Biao, 2003).

\section{Psychological wellbeing}

Only 4 articles discussed the psychological wellbeing of migrant workers. Studies show that migrant workers suffer from stress, depression and anxiety during an epidemic outbreak, given a wide range of challenges they face such as limited access to proper medical treatment, unemployment, and uncertainty about the future (Steege et al., 2019; Liem et al., 2020; Ding, 2014). In addition, undocumented migrant workers live in constant fear of being deported if they work with healthcare authority (Rothstein \& Coughlin, 2019). They also worry about being separated from their families in the host country during quarantine (Rothstein \& Coughlin , 2019).

\section{Intervention}

Eight studies discussed interventions to improve the physical or financial wellbeing of migrant workers. No interventions regarding psychological or social wellbeing were identified in these studies. 
The measures to promote physical wellbeing include quarantine, increased access to vaccinations, health screenings at the border, and promotion of hygiene strategies (Daniels, 2020; Hickey et al., 2014; Steege et al., 2019; Lin et al., 2015; MacPherson et al., 2007). Of these interventions, only one is COVID-19 related (Daniels, 2020) whereas others are about SARS, H1N1 or Ebola. Furthermore, the COVID-19 study focuses on specific strategies such as strengthening border control but allowing migrant workers who need ongoing medical attention (e.g. dialysis) to continue their treatment in their host country (Daniels, 2020). Compared to this COVID-19 study, studies on other epidemics identified interventions that are more systematic. For example, studies on SARS (Biao, 2003; Ding, 2014) and H1N1 (Ding, 2014; Hutchins et al., 2014) introduced a multi-agency intervention framework, which details the responsibilities of disease control in government organizations, healthcare institutions, public transportation, and employers of migrant workers.

Only one study has discussed the interventions to address the financial issue of migrant workers. In view of migrant workers' unstable financial status and possible income loss during the SARS outbreak, special government funds were set up in China to pay for migrant workers' treatment fee (Ding, 2014). In addition to this, employers were required to continue paying wages to migrant workers even though work had been suspended during the outbreak (Ding, 2014).

\section{Discussion}

This study represents one of the first to review the impact of major epidemics (including the COVID-19 pandemic) on the wellbeing of unskilled migrant workers. Overall, our findings consistently show that epidemic diseases have a negative impact on migrant workers, creating health risks, job insecurity, distress, and social discrimination. These findings are in line with an existing systematic review on migrants and refugees (Wilson et al., 2018). In discussing the wellbeing of migrant workers, the majority of the studies have taken different social factors into account (e.g., living condition, migratory status, linguistic and cultural barriers), which further elaborate on the wellbeing theories about how pre-existing socio-structural inequity affects one's wellbeing.

Our findings reviewed and analyzed migrant workers' experiences during epidemic outbreaks in 13 countries/regions. Each country/region has its own socio-demographics, disease situations, and social policies that could uniquely contribute to migrant workers' experiences. Therefore, cautions should be taken when interpreting these findings. Nonetheless, the negative impact of epidemics on migrant workers' wellbeing found across different countries suggests a global challenge that requires action from countries across the world.

Despite the consistent findings across the studies, several research gaps are identified. Compared to studies on physical, financial and social aspects of wellbeing, studies examining psychological wellbeing were limited. The multi-faceted nature of wellbeing suggests that each aspect of wellbeing has different impacts on an individual and each aspect interacts with the other (Kiefer, 2008). Limiting the discussion on psychological wellbeing will not only provide a biased view of migrant workers' experiences, but also underestimate its impact on migrant workers, such as their physical health and social engagement.

Fewer studies have focused on interventions. Furthermore, these studies mainly discussed interventions with an immediate effect (e.g., health screening and vaccination) while ignoring the approaches to assist migrant workers in the long run. One of the major issues that may have a long-lasting effect on migrant workers is unemployment. Research on disasters and natural hazards shows that economic downturn often occurs following an epidemic outbreak. An 
epidemic outbreak decreases people's demand for services due to fear of contagion, leading to closed businesses and loss of job in most sectors (e.g., retail, travel, insurance; Lee \& McKibbin, 2004). It is expected that the COVID-19 pandemic will wipe out equivalent to 195 million fulltime workers globally in the second quarter of 2020 (International Labour Organization, 2020). Migrant workers are particularly vulnerable to job loss due to their lack of social protection and citizenship entitlements, and the temporary nature of their jobs (Berntsen, 2016). Many migrant workers are the main breadwinners of their families and have been sending remittances home. Being jobless will create greater financial hardship for their families. Further, because migrants' rights to residence are tied to their employers, losing their jobs renders them vulnerable to deportation (Banki, 2013). Currently, there is a lack of official unemployment record for migrant workers across the countries. The most useful statistics available was reported by International Labour Organization (2020), which estimated that the relative poverty rate for informal workers (i.e., no employer's contribution to social security, no paid sick leave or annual leave) and their families will increase by $34 \%$ globally due to the pandemic. Therefore, what migrant workers need is not only healthcare interventions to survive the disease, but assistance to survive in the labor market post-pandemic.

The effectiveness of the interventions was largely unknown in these studies. As one of the guiding principles in the CDC Field Epidemiologic Manual (Hadler, Varma, Vugia, \& Goodman, 2018), developing evidence-based interventions helps to determine the feasibility of implementing an intervention in the population and provides evidence to improve the response to future outbreaks. The current pandemic has demonstrated its sweeping impact in the world through its unpredictable nature of outbursts, the rapid spread of the virus, and the large number of people affected. Using the components of the existing evidence-based interventions could improve the efficiency of the response to such a pandemic in the future.

In addition to the research gaps, some methodological limitations were identified in these studies. Only a few empirical studies were found on this subject, possibly due to the limited open-access data and pressure of time following an epidemic outbreak (Hadler et al., 2018). Among the empirical research, the majority utilized non-probability sampling, rendering the study subject to self-selection bias. One exception was Hickey et al (2014)'s study, which used random sampling to strengthen the external validity. In addition, there is a limitation associated with cross-sectional design employed by the quantitative study (Hickey et al., 2014) because the temporal precedence between the variables was unclear and no causal links can be drawn from the study. The research gaps and methodological limitations are also reflected in the quality assessment of this review as the majority of the studies were rated as medium quality.

\section{Implication to Practice and Research}

The substantial findings relating to the physical wellbeing of migrant workers reinforce the need for a universal health coverage during healthcare emergencies. As outlined in the Sustainable Development Goals (WHO, 2017), a universal health coverage includes benefits such as access to essential healthcare services and affordable medicines and vaccines. These benefits are crucial to migrant workers, considering the health disparities they experience in the host country.

The lack of long-term intervention in the studies calls for an approach that looks beyond an episode of disease and addresses its long-lasting impact on the society. As the COVID-19 pandemic persists, the issue of unemployment will continue to be a major challenge for migrant workers. The traditional approach is to deport migrant workers to their home countries. This not only deprives them of means of living, but also creates labor shortages once the economy 
starts to recover in the host country, especially in essential critical infrastructure. One possible solution is to register migrant workers in the government's unemployment record, conduct a demand and supply analysis, and relocate migrant workers to the industries where there is a labor shortage.

In addition, the findings suggest that the psychological needs of migrant workers have been overlooked during the epidemics. It is important for practitioners (e.g. social workers, counselors) to step in. Given the difficulty of providing in-person support due to social distancing, new interventions that involve technology should be considered. For example, with the "Cyber Social Work" strategy, the Singapore government has set up computers in migrant workers' dormitories for them to attend counseling sessions. Migrant workers can also use the computer to obtain COVID-19 information through an online translation portal. In view of the increasing discrimination against the migrant workers amid the epidemics, practitioners can disseminate evidence-based information on the cause and transmission of the disease using social media, combating rumors and misinformation. Furthermore, through sharing migrant workers' stories and voices during an epidemic outbreak, practitioners can raise the public awareness to migrant workers' challenges and advocate for migrant-inclusive response measures.

In terms of research implications, more evidence-based research is needed to examine migrant workers' wellbeing during epidemic outbreaks. For example, quantitative research can be conducted to compare the mental health outcomes between migrant workers and nonmigrant workers in the same country. Using a longitudinal study design, researchers can follow up with migrant workers post-outbreak to understand how their wellbeing is affected in the long run. Also, in order to gain a better insight into the effectiveness of an intervention, researchers can examine the changes in the wellbeing of migrant workers pre-and postintervention. These research agendas can be better achieved with more open-access data. Specifically, an international data sharing platform designated to migrant worker research could be established. Currently, there are several COVID-19 open data sharing portals (e.g., figshare, Crowdfight COVID-19). Building upon the existing efforts, the International Organization for Migration can collaborate with research institutes and NGOs to develop an international migrant worker data sharing network. The data will not only boost migrant worker research, but also provide evidence for service delivery and policy development in preparation for future epidemics.

\section{Authors}

Fei Wang

Case Western Reserve University, U.S.A.

fxw125@case.edu

Chao Tian

Ng Teng Fong General Hospital, Singapore

Weidi Qin

Case Western Reserve University, U.S.A.

\section{Publishing Timeline}

Received 15 June 2020

Accepted 21 July 2020

Published 13 August 2020 


\section{References}

Andrews, F. M., \& Withey, S. B. (1976). Social indicators of well-being. New York, NY: Plenum Press.

Baey, G., \& Yeoh, B. S. A. (2018). “The lottery of my life”: Migration trajectories and the production of precarity among Bangladeshi migrant workers in Singapore's construction industry. Asian and Pacific Migration Journal, 27(3), 249-272. https://doi.org/10.1177/0117196818780087

Banki, S. (2013). Precarity of place: A complement to the growing precariat literature. Global Discourse, 3(3-4), 450-463.

Berntsen, L. (2016). Reworking labour practices: On the agency of unorganized mobile migrant construction workers. Work, Employment and Society, 30(3), 472-488.

Bhopal, R. (2020). Covid-19: undocumented migrants are probably at greatest risk. BMJ, 369, 1673-1673. https://doi.org/10.1136/bmj.m1673

Biao, X. (2003). SARS and migrant workers in China: An institutional analysis. Asian and Pacific Migration Journal, 12(4), 467-500. https://doi.org/10.1177/011719680301200403

Daniels, J. P. (2020). Venezuelan migrants "struggling to survive" amid COVID-19. Lancet (London, England), 395(10229), 1023. https://doi.org/10.1016/S0140-6736(20)30718-2

Deshingkar, P., \& Grimm, S. (2005). Internal migration and development: A global perspective. Migration Research Series No. 19. https://publications.iom.int/books/mrs-ndeg19-internal-migration-anddevelopment-global-perspective

Diener, E., \& Biswas-Diener, R. (2008). Happiness: Unlocking the mysteries of psychological wealth. Malden, MA: Blackwell Publishing.

Ding, H. (2014). Transnational Quarantine Rhetorics: Public Mobilization in SARS and in H1N1 Flu. Journal of Medical Humanities, 35(2), 191-210. https://doi.org/10.1007/s10912-014-9282-8

Erizanu, P. (2020, April 16). Stranded or shunned: Europe's migrant workers caught in no-man's land. The Guardian. https://www.theguardian.com/world/2020/apr/16/stranded-or-shunned-europesmigrant-workers-caught-in-no-mans-land

EUPHA (European Public Health Association; 2020). Reducing the impact of coronavirus crisis on those "left behind" - Disadvantaged Migrants and Ethnic Minorities. https://eupha.org/repository/advocacy/MIG_statement_on_COVID19.pdf

Fisher, M. (2019). A theory of public wellbeing. BMC Public Health, 19(1), 1-12. https://doi.org/10.1186/s12889-019-7626-z

Frey, B.S., \& Stutzer, A. (2002). Happiness and economics. Princeton, NJ: Princeton University Press.

Guadagno, L. (2020). Migrants and the COVID-19 pandemic: An initial analysis. Migrant Research Series No. 60. https://publications.iom.int/books/mrs-no-60-migrants-and-covid-19-pandemic-initialanalysis

Hadler, J. L., Varma, J. K., Vugia, D. J., \& Goodman, R. A. (2018). Developing interventions. In CDC Field Epidemiology Manual. https://www.cdc.gov/eis/field-epi-manual/chapters/Interventions.html

Headey, B. W., \& Wearing, A. J. (1991). Subjective well-being: a stocks and flows framework. In Strack, F., Argyle, M., \& Schwarz, N. (Eds.). Subjective Wellbeing - An interdisciplinary perspective (pp. 4976). Oxford: Pergamon Press.

Hickey, J., Gagnon, A. J., \& Jitthai, N. (2014). Pandemic preparedness: Perceptions of vulnerable migrants in Thailand towards WHO-recommended non-pharmaceutical interventions: A cross-sectional study. BMC Public Health, 14(1), 1-9. https://doi.org/10.1186/1471-2458-14-665

Hobfoll, S. E. (1989). Conservation of resources: A new attempt at conceptualizing stress. American Psychologist, 44(3), 513-524. https://doi.org/10.1037/0003-066X.44.3.513

Hutchins, S. S., Truman, B. I., Merlin, T. L., \& Redd, S. C. (2009). Protecting vulnerable populations from pandemic influenza in the United States: A strategic imperative. American Journal of Public Health, 99(SUPPL. 2), 243-249. https://doi.org/10.2105/AJPH.2009.164814

International Labour Organization. (2020). ILO Monitor: COVID-19 and the world of work. Third edition.

https://www.ilo.org/wcmsp5/groups/public/@dgreports/@dcomm/documents/briefingnote/wcms 743146.pdf 
International Organization for Migration. (2020). World Migration Report 2020. https://www.iom.int/wmr

Jane, C. A. (2016). A Study on the internal migrant labour. Indian Journal of Applied Research. 6(4), 81 - 83.

Joanna Briggs Institute. (2017). Checklist for Prevalence Studies. https://joannabriggs.org/sites/default/files/2019-05/JBI Critical AppraisalChecklist for Prevalence Studies2017 0.pdf

Joanna Briggs Institute. (2017). Checklist for Qualitative Studies. https://joannabriggs.org/sites/default/files/2019-05/JBI Critical AppraisalChecklist for Qualitative Research2017 0.pdf

John Hopkins University \& Medicine. (2020). COVID-19 Map. https://coronavirus.jhu.edu/us-map

Kluge, H. H. P., Jakab, Z., Bartovic, J., Danna, V., \& Severoni, S. (2020). Refugee and migrant health in the COVID-19 response. The Lancet, 395(10232), 1237-1239. doi: 10.1016/s0140-6736(20)30791-1

Kobau, R., Bann, C., Lewis, M., Zack, M. M., Boardman, A. M., Boyd, R., Lim, K. C., Holder, T., Hoff, A. K., Luncheon, C., Thompson, W., Horner-Johnson, W., \& Lucas, R. E. (2013). Mental, social, and physical well-being in New Hampshire, Oregon, and Washington, 2010 Behavioral Risk Factor Surveillance System: implications for public health research and practice related to Healthy People 2020 foundation health measures on well-being. Population health metrics, 11(1), 19. https://doi.org/10.1186/1478-7954-11-19

Lee, J. W., \& McKibbin, W. J. (2004). Estimating the global economic costs of SARS. In Learning from SARS: preparing for the next disease outbreak: workshop summary (p. 92). Washington, DC: National Academies Press.

Liem, A., Wang, C., Wariyanti, Y., Latkin, C. A., \& Hall, B. J. (2020). The neglected health of international migrant workers in the COVID-19 epidemic. The Lancet Psychiatry, 7(4). https://doi.org/10.1016/S2215-0366(20)30076-6

Lin, L., Hall, B. J., Khoe, L. C., \& Bodomo, A. B. (2015). Ebola outbreak: From the perspective of African migrants in China. American Journal of Public Health, 105(5), 5. https://doi.org/10.2105/AJPH.2015.302649

MacPherson, D. W., Gushulak, B. D., \& Macdonald, L. (2007). Health and foreign policy: Influences of migration and population mobility. Bulletin of the World Health Organization, 85(3), 200-206. https://doi.org/10.2471/BLT.06.036962

Menaghan, E. G, (1983). Individual coping efforts: Moderators of the relationship between life stress and mental health outcomes. In H. B. Kaplan (Ed.), Psychosocial stress: Trends in theory and research (pp.157-191). New York: Academic Press.

Onoma, A. K. (2017). The Making of Dangerous Communities: The "Peul-Fouta" in Ebola-Weary Senegal. Africa Spectrum, 52(2), 29-51. https://doi.org/10.1177/000203971705200202

PICUM. (Platform for International Cooperation on Undocumented Migrants; 2020). The Covid-19 pandemic: We need urgent measures to protect people and mend the cracks in our health, social protection and migration systems. https://picum.org/wp-content/uploads/2020/03/COVID-19Statement-March-2020.pdf

Qiu, P., Caine, E., Yang, Y., Chen, Q., Li, J., \& Ma, X. (2011). Depression and associated factors in internal migrant workers in China. Journal of affective disorders, 134(1-3), 198-207. https://doi.org/10.1016/j.jad.2011.05.043

Rothstein, M. A., \& Coughlin, C. N. (2019). Ensuring compliance with quarantine by undocumented immigrants and other vulnerable groups: Public health versus politics. American Journal of Public Health, 109(9), 1179-1183. https://doi.org/10.2105/AJPH.2019.305201

Schoch-Spana, M., Bouri, N., Rambhia, K. J., \& Norwood, A. (2010). Stigma, health disparities, and the 2009 H1N1 influenza pandemic: How to protect Latino farmworkers in future health emergencies. Biosecurity and Bioterrorism, 8(3), 243-254. https://doi.org/10.1089/bsp.2010.0021

Steege, A. L., Baron, S., Davis, S., Torres-Kilgore, J., \& Sweeney, M. H. (2009). Pandemic influenza and farmworkers: The effects of employment, social, and economic factors. American Journal of Public Health, 99(SUPPL. 2), 308-316. https://doi.org/10.2105/AJPH.2009.161091 
The Lancet. (2020). COVID-19 will not leave behind refugees and migrants. The Lancet, 395(10230), 1090. https://doi.org/10.1016/S0140-6736(20)30758-3

The U.S. Centers for Disease Control and Prevention. (2018). The Well-being Concepts. https://www.cdc.gov/hrqol/wellbeing.htm

United Nations Statistics Division. (1998). Recommendations on Statistics of International Migration, Revision 1. United Nations. https://unstats.un.org/unsd/publication/seriesm/seriesm 58rev1e.pdf

Wilson, L., Rubens-Augustson, T., Murphy, M., Jardine, C., Crowcroft, N., Hui, C., \& Wilson, K. (2018). Barriers to immunization among newcomers: A systematic review. Vaccine, 36(8), 1055-1062. https://doi.org/10.1016/j.vaccine.2018.01.025

World Bank (2020). COVID-19 Crisis through a migration lens. http://documents.worldbank.org/curated/en/989721587512418006/pdf/COVID-19-CrisisThrough-a-Migration-Lens.pdf

World Health Organization. (2014). A brief guide to emerging infectious diseases and zoonoses. WHO Regional Office for South-East Asia. https://apps.who.int/iris/handle/10665/204722

World Health Organization. (2017). Sustainable Development Goals 3: Ensure healthy lives and promote wellbeing for all at all ages. https://www.who.int/sdg/targets/en/

World Health Organization. (2020). WHO Timeline - COVID-19. https://www.who.int/newsroom/detail/27-04-2020-who-timeline---covid-19 


\section{Appendix I}

Data Extraction Form for Screening

\begin{tabular}{|c|c|c|c|c|c|c|c|c|c|}
\hline \multicolumn{4}{|c|}{ Part A: Study Information } & \multicolumn{2}{|c|}{ Part B: Initial Screening } & \multicolumn{3}{|c|}{ Part C: Eligibility Decisions } & \multirow{2}{*}{\begin{tabular}{l}
\multicolumn{1}{c}{ Part D: } \\
Assessment \\
of Study \\
Quality \\
D1. Overall \\
Score of the \\
Study
\end{tabular}} \\
\hline $\begin{array}{l}\text { A1. } \\
\text { Ref } \\
\text { ID }\end{array}$ & $\begin{array}{l}\text { A2. } \\
\text { Title } \\
\text { and } \\
\text { Author } \\
\text { (s) }\end{array}$ & $\begin{array}{l}\text { A3. Date } \\
\text { of } \\
\text { Extraction }\end{array}$ & $\begin{array}{l}\text { A4. Type of Study } \\
\text { [1] Intervention } \\
\text { [2] Observational } \\
\text { (quantitative): } \\
\text { cross-sectional, } \\
\text { longitudinal } \\
\text { [3] Mixed method } \\
\text { [4] Qualitative } \\
\text { [5] Descriptive, } \\
\text { correlational or } \\
\text { case studies } \\
\text { [6] Theoretical or } \\
\text { position paper, } \\
\text { editorial or } \\
\text { commentary } \\
\text { [7] Systematic } \\
\text { review on the well- } \\
\text { being of migrant } \\
\text { workers or related } \\
\text { interventions } \\
\text { during the major } \\
\text { epidemic infectious } \\
\text { diseases (STOP, } \\
\text { code as Harvest on } \\
\text { C1) } \\
\text { [8] Practice } \\
\text { guideline } \\
\text { [If can't tell, } \\
\text { RETRIEVE FULL } \\
\text { TEXT] }\end{array}$ & $\begin{array}{l}\text { B1. Is this paper } \\
\text { about migrant } \\
\text { workers/foreign } \\
\text { workers/internal } \\
\text { migrant } \\
\text { workers/domestic } \\
\text { helpers? } \\
\text { [1] Yes } \\
\text { [2] No (STOP, } \\
\text { code as excluded } \\
\text { on C1) } \\
\text { [If can't tell, } \\
\text { RETRIEVE FULL } \\
\text { TEXT] }\end{array}$ & $\begin{array}{l}\text { B2. Is this } \\
\text { paper about } \\
\text { the epidemic } \\
\text { infectious } \\
\text { diseases } \\
\text { during the } \\
\text { past } 20 \text { years } \\
\text { [i.e. COVID- } \\
\text { 19, SARS, } \\
\text { H1N1, MERS, } \\
\text { Ebola]? } \\
\text { [1] Yes } \\
\text { [2] No (STOP, } \\
\text { code as } \\
\text { excluded on } \\
\text { C1) } \\
\text { [If can't tell, } \\
\text { RETRIEVE } \\
\text { FULL TEXT] }\end{array}$ & $\begin{array}{l}\text { C1. Is this } \\
\text { paper about } \\
\text { the well- } \\
\text { being of } \\
\text { migrant } \\
\text { workers, or } \\
\text { the } \\
\text { intervention } \\
\text { to improve } \\
\text { the well- } \\
\text { being of } \\
\text { migrant } \\
\text { workers? } \\
\text { [1] Yes } \\
\text { [2] No } \\
\text { (STOP, code } \\
\text { as excluded } \\
\text { on C1) }\end{array}$ & $\begin{array}{l}\text { C2. } \\
\text { Paper } \\
\text { Status: } \\
\\
{[1]} \\
\text { Excluded } \\
{[2]} \\
\text { Included } \\
{[3]} \\
\text { Harvest } \\
{[4] \text { Full }} \\
\text { Text N/A }\end{array}$ & $\begin{array}{l}\text { C3. If } \\
\text { excluded, } \\
\text { what was } \\
\text { the } \\
\text { reason? } \\
\text { List the } \\
\text { question } \\
\text { number } \\
\text { that } \\
\text { determines } \\
\text { the study } \\
\text { should be } \\
\text { excluded } \\
\text { [Choose } \\
\text { from Part } \\
\text { B or C] }\end{array}$ & \\
\hline
\end{tabular}




\section{Appendix II}

Guideline for Assessing the Quality of the Included Studies

Reviewer:

Date:

Author:

Year:

Ref No.

1. Were study participants sampled in an appropriate way? (Yes/No/Uncertain)

2. Were the study subjects clearly defined for the coder to identify their eligibility of the current review? (Yes/No/Uncertain)

3. Did all study subjects meet the eligibility of the current review (e.g. all unskilled migrant workers versus a combination of unskilled and skilled professionals) (Yes/No/Uncertain)

4. Was there appropriate statistical analysis? (Yes/No/Uncertain)

5. Was the study about the well-being of migrant workers and intervention for improving the well-being? (Yes/No/Uncertain)

6. Did the study discuss more than one aspect of well-being of migrant workers? (Yes/No/Uncertain)

7. Did the study propose specific steps or protocol for the intervention? (Yes/No/Uncertain)

8. Did the study assess the effectiveness of the intervention? (Yes/No/Uncertain)

9. Did the study discuss the implication of the intervention for future epidemic infectious diseases? (Yes/No/Uncertain)

Total Score

*Yes $=1 \mathrm{No}=0$ Uncertain: the third reviewer to review and then give a score

Quality (Low/Medium/High)

*Low $0-3$ Medium 4-6 High 7 - 9 